\title{
THE CONTRIBUTION OF THE DEFENCE ACT TO THE FIGHT AGAINST PIRACY
}

\section{Introduction}

The recent events off the Horn of Africa have drawn attention again to the problem of piracy. Less publicized is an increase in pirate activities in West Africa. Despite centuries of repression, this criminal behaviour continues to present a serious challenge to the safety of shipping on which international trade depends. And the phenomenon is spreading worryingly close to a South African coast which witnessed it in the past. Indeed, pirates operated off the coast of Southern Africa as early as 1508 , with pirate activity peaking at the end of the $17^{\text {th }}$ century (see Bulpin "Pirates and Piracy" in Potgieter (ed) Standard Encyclopedia of Southern Africa Vol 8 (1973) 581 for a detailed discussion of the predation of the pirates off the south and east coasts of Africa).

Piracy may be generally defined as "unlawful depredation at sea involving the use or threat of violence possibly, but not necessarily, involving robbery" (Murphy Small Boats, Weak States, Dirty Money (2009) 7, although, as will be seen below, the definition of piracy is somewhat more circumscribed in terms of both South African criminal law and international law). The purpose of this paper is to examine the contribution of the Defence Act 42 of 2002 (hereinafter "the Act") to the fight against piracy (see in general Fouché Policing Piracy and Armed Robbery of Ships in South Africa's Territorial Waters and Contiguous Zone (unpublished DTech thesis, Tshwane University of Technology (2006); Fouché "Policing Maritime Piracy in Southern Africa" 2006 19(3) Acta Criminologica 180; and Fouché "Policing of Piracy and Armed Robbery Perpetrated Against Ships: The Role of Interstate Partnersips in Africa" 2007 20(1) Acta Criminologica 110).

South Africa has a duty to co-operate to the fullest possible extent in the repression of piracy on the high seas in terms of the 1982 UN Convention on the Law of the Sea (hereinafter "LOSC") (art 100. South Africa ratified LOSC in 1997 after it had come into effect in 1994). In order to do so, South Africa is expected to exercise its legislative, executive and judicial jurisdictions.

\section{Legislative jurisdiction}

There is no doubt that states may criminalize piracy in their domestic legal system (Sohn and Noyes Cases and Materials on the Law of the Sea (2004) 180). Gardiner and Lansdown (South African Criminal Law and Procedure Vol II: Specific Offences 6ed (1957) 1059) distinguish between the crime of piracy jure gentium ("as recognized by the Law of Nations") and statutory piracy. 
Piracy has been a crime under customary international law for centuries (Dugard International Law 3ed (2005) 157). Because customary international law is law in South Africa (Dugard 51-52), piracy is also a common-law crime to the extent that it is not inconsistent with the Constitution or an Act of Parliament (s 232 of the Constitution. See contra Devine "Legal Protection of Offshore Installations Outside South African Territorial Waters" 199311 Journal of Energy and Natural Resources Law 290-291).

Statutory piracy is established in terms of the English legislation (Gardiner and Lansdown 1061-1062). It is significant that the crime of piracy was not created in terms of the erstwhile South African legislation. It seems that the legislature believed that it was not necessary to do so because acts which may have fallen within the ambit of piracy could be prosecuted on other grounds for liability. These could either take the form of the common-law crimes of robbery, assault or murder, as the case may be, or statutory offences such as contraventions of section 1 of the Intimidation Act 72 of 1982, firearms offences in terms of the Firearms Control Act 60 of 2000 (previously the Arms and Ammunition Act 75 of 1969), or section 320 of the Merchant Shipping Act 57 of 1951. However, Parliament recently changed its approach. Indeed, section 24(3) of the Act makes it an offence to commit an act of piracy, in contrast with the Defence Act 44 of 1957.

Piracy is defined in terms of section 24(1), for purposes of the Act, as

"(a) any illegal act of violence or detention, or any act of depredation, committed for private ends by the crew, including the Master, or the passengers of a private ship or a private aircraft, and directed -

(i) on the high seas, against another ship or aircraft, or against persons or property on board such ship or aircraft;

(ii) against a ship, aircraft, persons or property in a place outside the jurisdiction of any state;

(b) any act of voluntary participation in the operation of a ship or of an aircraft with knowledge of facts making it a ship or aircraft contemplated in subsection (1); and

(c) any act of inciting or of intentionally facilitating an act contemplated in paragraph (a) or (b)."

(In terms of $s$ 24(2) of the Act, "[a]ny act of piracy committed by the crew of a warship or military aircraft, government ship or government aircraft which has mutinied and taken control of such ship or aircraft, must for purposes of [section 24] be regarded as having been committed by the crew of a private ship or aircraft". This provision corresponds to art 102 of LOSC).

This definition varies only very slightly from the definition of "piracy" in article 101 of LOSC:

"Piracy consists of any of the following acts:

(a) any illegal acts of violence or detention, or any act of depredation, committed for private ends by the crew or the passengers of a private ship or a private aircraft, and directed:

(i) on the high seas, against another ship or aircraft, or against persons or property on board such ship or aircraft;

(ii) against a ship, aircraft, persons or property in a place outside the jurisdiction of any State; 
(b) any act of voluntary participation in the operation of a ship or of an aircraft with knowledge of facts making it a pirate ship or aircraft;

(c) any act of inciting or of intentionally facilitating an act described in subparagraph (a) or (b)."

Firstly, the Act refers to "any illegal act of violence or detention", while LOSC refers to "any illegal acts of violence or detention" (authors' own emphasis). The reason why the word "act" is in the plural is unclear, especially in view of the fact that it is used in the singular in the remainder of article 101 (this was already the situation in art 15 of the 1958 Convention on the High Seas). It is submitted that the difference is immaterial and that the wording of section 24(1) is more consistent than that of article 101.

Secondly, the Act makes it clear that the master of a ship must be seen as a member of the crew, while LOSC is silent on this issue. LOSC does not define the term "crew". In most of its provisions, it is clear that the term does not include the ship's master. An example is article 94(4)(c), which compels the flag state to ensure that "the master, officers and, to the extent appropriate, the crew are fully conversant with and required to observe the applicable international regulations concerning the safety of life at sea ..." However, this distinction between master, officers and crew is not made in article 292, which provides for the "[p]rompt release of vessels and crews". In such a case, there is no basis to exclude the master and officers from the "crew" and argue that there is no duty to release the former as promptly as the vessel and the rest of the crew. In the case of piracy, there is no reason not to include the master (and the officers) among the crew. A reason why s 24(1) of the Act expressly mentions the master of the ship is that South African law "has traditionally regarded the master separately from ... other persons serving on board" (Hare Shipping Law and Admiralty Jurisdiction in South Africa (1999) 205). This is illustrated by the Merchant Shipping Act, which defines the term "crew" as meaning "all seamen on board a ship" (s 2(1)). In turn, the term "'seaman' means any person (except a master, pilot or apprentice-officer) employed or engaged in any capacity as a member of the crew of a ship" (s 2(1)).

Finally, section 24(1)(c) of the Act uses the term "contemplated", while article 101(c) uses the term "described". The difference appears once again to be immaterial.

The reliance of the South African legislature on the LOSC definition avoided difficulties arising from possible differences between the South African definition and the LOSC definition. However, it also imported into South African law the uncertainties associated with the LOSC definition.

For instance, in terms of which legal system does one determine whether an act of violence or detention is illegal? Is it in terms of international law or domestic law? And in the latter case, which domestic law? That of the flag state of the pirate ship, that of the flag state of the other ship or that of the flag state of the ship taking action against the pirates? The fact that the phrase is now part of a provision of a South African statute may lead to the conclusion that, as far as South African law is concerned, the standard is that of South African law itself. This raises jurisdictional difficulties. For 
example, on which valid ground would South Africa be entitled to determine whether an act of violence or detention is illegal if that act is perpetrated on the high seas by the crew of a ship which does not fly the South African flag, against non-South African nationals on another ship which also does not fly the South African flag? As far as South African law is concerned, an act of violence or detention would be regarded as unlawful when contrary to existing crimes such as assault and kidnapping respectively, and where there was no justification for such actions rendering the actions lawful. On the other hand, when does an act qualify as an "act of depredation"? This phrase has yet to be defined in South African law.

Moreover, how must one understand the term "ship" in view of the fact that the term is not defined in the Act and that "[t]here is no uniform approach by the legislature on what constitutes a 'ship' in [South African] law" (Hare 121).

Finally, what is meant by the phrase "a place outside the jurisdiction of any state" in section 24(1)(a)(ii)? The wording is wide enough to encompass the high seas, but the latter is dealt with in section 24(1)(a)(i). This leaves land territory, such as a guano island (Rubin The Law of Piracy (1999) 353), which has the status of terra nullius (Sohn and Noyes 169). But this excludes the internal waters and territorial sea, which stretch up to around $22 \mathrm{~km}$ from the shore (art 2 LOSC). This is problematical in view of the fact that most pirate attacks take place close to the coast, especially within the internal waters and territorial sea (Menefee Contemporary Piracy and International Law (1995) 63). This apparent gap is addressed by the fact that all laws in force in South Africa, including the common law, apply also in the South African internal waters and territorial sea (ss 3(2) and 4(2) of the Maritime Zones Act 15 of 1994). As a result, piracy in those waters may be prosecuted on the basis of South African common-law or statutory offences such as assault or robbery. It would, however, not be possible to prosecute on the basis of the common-law crime of piracy as domesticated from customary international law because the latter, as codified in article 101 of LOSC, only provides for the commission of the crime on the high seas or in a place outside the jurisdiction of any state. As far as the exclusive economic zone is concerned, attempts during the 1973-1982 Third UN Conference on the Law of the Sea at wording the LOSC definition in such a way that it also includes acts committed in that zone were all unsuccessful (Menefee 32-34). If one interprets this as evidence of the fact that customary international law does not provide for the commission of the crime of piracy in the exclusive economic zone, piracy in that zone is not a crime in South African law either. There is, however, strong support for the view that customary international law does provide for the commission of the crime of piracy in the exclusive economic zone (see for instance Brown The International Law of the Sea (1994) I 303; Sohn, Juras, Noyes and Franckx Law of the Sea in a Nutshell (2010) 82). This is based on article 58(2) of LOSC which provides that articles 88 to 115 of LOSC, including therefore articles 100 to 107 that deal with piracy, "apply to the exclusive economic zone in so far as they are not incompatible with" the provisions of LOSC regarding the exclusive economic zone (part V). If this assessment is correct, it would be possible in South 
Africa to prosecute pirates in the South African exclusive economic zone on the basis of section 24(1)(a)(ii). Either way, it would not be possible to prosecute on the basis of South African common-law or statutory offences such as assault or robbery. This is because South African law does not apply in toto in the South African exclusive economic zone (there is no equivalent to ss 3(2) and 4(2) of the Maritime Zones Act 15 of 1994 for the zone) and therefore cannot fill the gap left by the Act, except on and $500 \mathrm{~m}$ around artificial installations located in the zone (ss 1 and 9 of the Maritime Zones Act read with s 1 of the Marine Traffic Act 2 of 1981).

\section{Enforcement jurisdiction}

International law allows a warship which encounters a foreign ship on the high seas to board it (art 110(1)(a) of LOSC) if it has reasonable ground to suspect the ship is engaged in piracy. This decision is not to be taken lightly because, "[i]f the suspicions prove to be unfounded, and provided that the ship boarded has not committed any act justifying them, it [must] be compensated for any loss or damage that may have been sustained" (art 110(1)(a) of LOSC). In the case of piracy, section 25(1) of the Defence Act authorizes an officer of the Defence Force to "seize a ship or aircraft and the property on board, and arrest any person on board, in accordance with articles 105 and 107 of UNCLOS". This means that the seizure may only be carried out by a warship or military aircraft, or other ship or aircraft "clearly marked and identifiable as being on government service and authorized to that effect" (art 107 of LOSC). This also means that the seizure may only take place on the high seas or in any other place outside the jurisdiction of any state (art 105 of LOSC). It finally means that the ship seized may only be the ship "taken by piracy and under the control of pirates" or the pirate ship itself (art 105 of LOSC). The latter is defined as a ship which either "is intended by the persons in dominant control to be used for the purpose of committing one of the acts referred to in article 101" of LOSC, or which "has been used to commit any such act, so long as it remains under the control of the persons guilty of that act" (art 103 of LOSC). Caution is required when deciding upon the seizure of a ship on ground of piracy because, if it is "effected without adequate grounds, the State making the seizure [is] liable to the State the nationality of which is possessed by the ship ... for any loss or damage caused by the seizure" (art 106 of LOSC).

Any ship or property seized, or any person arrested in terms of section 25(1) "must as soon as possible be brought to the Republic or to any other authority determined by the Minister of Foreign Affairs, with the concurrence of the Ministers of Defence and of Justice, to be dealt with in accordance with applicable law" (s 25(3) of the Act). It is unclear whether the "other authority" must be a South African authority located outside South Africa (an authority which would only exist in exceptional circumstances) or whether it may, and would in most instances be, a foreign authority. In the latter case, the "applicable law" in terms of which the ship, property or person(s) would be dealt with would be that of the foreign State concerned. The South African ministers would arguably have to ensure, should they contemplate 
handing any arrested person to a foreign authority, that South Africa is not "party to the imposition of cruel, inhuman or degrading punishment". (Mohamed $v$ President of the RSA 20013 SA 893 CC 59. In this case, the person concerned was within the South African land territory when he was handed over to foreign authorities. On this judgment, see $\mathrm{N}$ Botha "Deportation, Extradition and the Role of the State" 200126 SAYIL 227239).

LOSC allows the courts of the State which carried out the seizure to "decide upon the penalties to be imposed, and ... also determine the action to be taken with regard to the ships ... or property, subject to the rights of third parties acting in good faith" (art 105). The Defence Act gives jurisdiction to any court in the Republic designated by the Director of Public Prosecutions to try a person who is accused of committing an act of piracy and, upon conviction, that person "is liable to a fine or to imprisonment for any period, including life imprisonment" (s 24(3)).

\section{Conclusion}

The enactment of sections 24 and 25 of the Defence Act added a much needed weapon in the armoury available in South African law to deal with piracy as defined in article 101 of LOSC. Unfortunately, that weapon is neither sufficient nor without weaknesses. A similar problem is experienced at the international level. The South African legislature will have to watch closely the efforts of the international community to improve the legal tools at its disposal to increase maritime security, and take the necessary steps to follow suit in due course.

PHG Vrancken

Nelson Mandela Metropolitan University, Port Elizabeth

and

SV Hoctor

University of KwaZulu-Natal, Pietermaritzburg 